\title{
NILAI KARAKTER RELIGIUS CERITA RAKYAT PERTAPAAN RATU KALINYAMAT UNTUK SISWA SEKOLAH DASAR
}

\author{
Erlina Rafika Wardani ${ }^{1}$, Irfai Fathurohman ${ }^{2}$, Mohammad Syafruddin Kuryanto ${ }^{3}$ \\ ${ }_{1,2,3}$ Universitas Muria Kudus, Indonesia
}

\section{Informasi Artikel}

Riwayat Artikel:

Diserahkan: 21-11-2020

Direvisi: 21-12-2020

Dipublikasikan: 11-01-2021

\section{Kata-kata kunci:}

Nilai karakter

Religius

Cerita rakyat

Kalinyamat

Sekolah dasar

\begin{abstract}
ABSTRAK
Penelitian ini bertujuan untuk mendeskripsikan nilai religi pada Cerita Rakyat Pertapaan Ratu Kalinyamat Jepara pada siswa SD. Penelitian ini menggunakan metode kualitatif deskriptif dengan pendekatan fenomenologi. Objek penelitian ini adalah Folkore Pertapaan Ratu Kalinyamat. Ada 6 informan penting yang menjadi sumber data dari penelitian ini, yaitu: Kepala Desa Tulakan, Pengurus Kediaman Ratu Kalinyamat, Jemaah Haji, Tokoh Masyarakat, Guru Sekolah Dasar dan Siswa Sekolah Dasar. Data diperoleh melalui wawancara mendalam, observasi dan dokumentasi. Uji validitas penelitian ini menggunakan teknik triangulasi. Teknik analisis data menggunakan reduksi data, penyajian data dan verifikasi data. Nilai karakter religius dalam cerita rakyat penebusan dosa ratu kalinyamat memiliki 5 dimensi yaitu keyakinan agama, praktik keagamaan, perasaan religius, pengetahuan agama dan efek religius. Semua dimensi tersebut merupakan demintions yang mengukur sejauh mana perilaku seseorang dimotivasi oleh ajaran agama masyarakat dalam kehidupan sehari-hari.
\end{abstract}

This is an open access article under the CC BY-SA license.

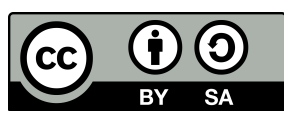

\section{Penulis Korespondensi:}

Erlina Rafika Wardani, Universitas Muria Kudus,

Jl. Lingkar Utara, Kayuapu Kulon, Gondangmanis, Bae, Kabupaten Kudus, Jawa Tengah, Indonesia.

Email: erlinarafika36@gmail.com

\section{PENDAHULUAN}

Masyarakat dan kebudayaan merupakan satu kesatuan yang tidak bisa dipisahkan. Kebudayaan memiliki hubungan yang sangat erat dengan masyarakat (Faishol \& Bakri, 2014). Jika dilihat dari berbagai pihak, nilai karakter yang dapat diambil sangat banyak. Semua persoalan hidup dan kehidupan manusia, termasuk dalam hal ini mengenai nilai-nilai karakter yang penting dalam kehidupan digolongkan menjadi tiga golongan, yaitu (1) nilai yang terkait antara manusia dan diri sendiri; (2) hubungan manusia dengan manusia lain dalam lingkup sosial dan alam; dan (3) hubungan manusia dengan Tuhan (Nurgiyantoro, 2015). Kebudayaan adalah merupakan suatu kompleks gagasan dan pikiran manusia bersifat tidak teraga. Kebudayaan akan terwujud sesuai dengan keadaan, gaya hidup dan pandangan yang konkrit (Lozar \& Rapoport, 1970).

Wilayah pantura bagian timur Propinsi Jawa Tengah, yakni Jepara, Kudus, Pati, dan Rembang memiliki cerita rakyat yang sangat melimpah baik lisan maupun tulis (Kanzunnudin, 2015). Salah satunya adalah cerita rakyat pertapaan Ratu Kalinyamat yang ada di Desa Tulakan, Kecamatan Donorojo, Kabupaten Jepara. Cerita rakyat merupakan bagian kebudayaan bersifat kolektif yang diwariskan oleh nenek moyang (leluhur) kepada generasi penerusnya melalui budaya lisan maupun tulis secara turun temurun yang berisi tentang nilainilai kehidupan dengan berbagai variasi bentuk seperti prosa (dongeng, mite, legenda), teka teki, tembang, puisi 
rakyat (pantun, gurindam, syair), bahasa rakyat (logat), puisi , adat istiadat, kepercayaan rakyat, bunyi isyarat untuk komunikasi rakyat (kentongan, genderang), pakaian tradisional, musik rakyat (Kanzunnudin, 2015).

Cerita rakyat Pertapaan Ratu Kalinyamat juga memiliki petilasan yang ada di Desa Tulakan, Kecamatan Donorojo, Kabupaten Jepara. Berdasarkan penelitian yang telah dilakukan oleh peneliti, cerita rakyat Pertapaan Ratu Kalinyamat memiliki nilai religius yang sangat kental dimata masyarakat sekitar. Nilai religius tersebut sedikit banyak telah mandarah daging dengan masyarakat Desa Tulakan dari anak-anak hingga dewasa. Dalam hal ini pendidikan karakter religuis perlu ditekankan lagi dalam pendidikan karakter generasi penerus, terutama anak usia sekolah dasar.

Menurut Undang-Undang Republik Indonesia Nomor 20 Tahun 2003 tentang Sistem Pendidikan Nasional menyatakan bahwa pendidikan nasional bertujuan mengembangkan kemampuan dan membentuk watak serta peradaban bangsa yang bermanfaat dalam rangka mencerdaskan kehidupan bangsa, bertujuan untuk berkembangnya potensi peserta didik agar menjadi manusia yang beriman dan bertakwa kepada Tuhan Yang Maha Esa dan menjadi warga negara yang demokratis serta bertanggung jawab.

Ada tiga fokus pendidikan karakter, yaitu berfokus pada nilai-nilai ajaran, nilai klarifikasi, dan pengembangan moral (Agung, 2018). Sejalan dengan tiga fokus pendidikan karakter tersebut,pendidikan karakter merupakan sesuatu yang sangat penting dengan tujuan untuk menerapkan nilai-nilai kebaikan dalam kehidupan sehari-hari (Sugirin, 2018). Berdasarkan dari teori diatas pendidikan karakter mampu memberikan efek terbaik untuk membangun pendidikan yang berhasil dalam meningkatkan moral, budi pekerti siswa di dalam sebuah lembaga pendidikan formal maupun non formal.

Pendidikan karakter dapat bersumber dari mana saja, tidak terkecuali melalui kebudayaan. Dalam hal ini adalah berupa cerita rakyat, salah satunya adalah Cerita Rakyat Pertapaan Ratu Kalinyamat yang terletak di wilayah Desa Tulakan, Kecamatan Donorojo, Kabupaten Jepara, Provinsi Jawa Tengah. Tokoh Ratu Kalinyamat yang dikenal masyarakat sebagai tokoh legendaris dan dianggap sakti oleh masyarakat. Berdasarkan nilai karakter Cerita Rakyat Pertapaan Ratu Kalinyamat itulah, peneliti merasa perlu untuk melakukan penelitian berjudul Nilai Karakter Pertapaan Cerita Rakyat Ratu Kalinyamat, Jepara.

\section{METODE PENELITIAN}

Penelitian kualitatif yaitu yang dilakukan mengutamakan kedalaman penghayatan terhadap interaksi antar konsep yang sedang dikaji secara empiris. Penelitian kualitatif mengkaji perspektif partisipan dengan strategi-strategi yang bersifat interaktif dan fleksibel. Penelitian kualitatif ini dilakukan dengan pengumpulan data yang pada umumnya seorang peneliti bisa menemukan data penelitian dalam bentuk kata-kata maupun gambar. Dapat berupa transkip-transkip wawancara, catatan data lapangan, dokumen pribadi, foto-foto, dan lain-lainnya.

Lokus penelitian Penelitian ini mengambil lokasi di Desa Tulakan Kecamatan Donorojo Kabupaten Jepara, dimana lokasi ini memiliki cerita rakyat Pertapaan Ratu Kalinyamat dan tradisi-tradisi yang masih berjalan sampai saat ini.Dalam penelitian ini mengambil tentang nilai karakter yang terkandung dalam cerita rakyat Pertapaan Ratu Kalinyamat.

Teknik pengumpulan data yangdigunakan adalah menggunakan Triangulasi Data melalui observasi, wawancara dan dokumentasi. Terdapat 6 informan penting yang menjadi sumber data dari penelitian ini, yaitu: Kepala Desa Tulakan, juru kunci tempat pertaaan Ratu Kalinyamat, peziarah, tokoh masyarakat, guru sekolah dasar dan siswa sekolah dasar.

Data hasil dari penelitian tersebut dianalisis dan disajikan dalam bentuk deskripsi sehingga peneliti akan memperoleh data yang objektif. Analisis data kualitatif dilakukan pada saat pengumpulan data berlangsung dan setelah pengumpulan data pada periode tertentu (Sugiyono, 2016). Uji validitas menggunakan teknik triangulasi sebagai teknik pemeriksaan data (Moleong, 2017). Hal tersebut dapat dicapai dengan cara sebagai berikut: (1) Membandingkan data hasil pengamatan dengan hasil wawancara; (2) Membandingkan keadaan dan perspektif seseorang dengan berbagai pendapat dan pandangan orang lain, selain guru dan siswa; (3) Membandingkan hasil wawancara dengan isi suatu dokumen yang berkaitan.

Teknik analisis data yang digunakan dalam penelitian ini adalah model analisis intraktif Miles \& Huberman dengan melakukan data reduction (reduksi data), display (penyajian data), conclusion and verification (menarik kesimpulan dan verifikasi) (Miles \& Huberman, 2012). 


\section{HASIL DAN PEMBAHASAN}

Cerita rakyat mengandung nilai-nilai karakter dalam masyarakat bahkan kebudayaan yang ada berkesinambungan langsung dengan berbagai fenomena budaya, sosial, tingkah, pola pikir, dan cara berkomunikasi masyarakat. Salah satu unsur yang membangun cerita rakyat adanya karakter yang muncul dalam suatu cerita, baik karakter positif maupun negatif. Melalui tokoh dalam cerita yang mengisahkan kehidupan, memuat nilainilai kebaikan, kejujuran, kesetiaan, perjuangan, kesabaran, dan sejenisnya digunakan sebagai media dalam membentuk karakter positif pada siswa secara efektif, disampaikan melalui alur cerita dan metafora sehingga prosesnya berlangsung menyenangkan dan tidak menggurui.

\subsection{Cerita Rakyat Ratu Kalinyamat}

Menurut buku Babat Tanah Jawa, Ratu Kalinyamat adalah putri pangeran Trenggono dan cucu Raden Patah (sultan Demak yang pertama). Dari perkawinannya dengan Putri Cina Raden Patah mempunyai enam orang putra, yang paling tua seorang putri Ratu Mas, menikah dengan Pangeran Cirebon. Adik-adiknya berjumlah lima orang, semuanya laki-laki, masing-masing Pangeran Sabrang Ler (lor), Pangeran Sedo Lepen, pangeran Trenggono, Raden Kunduran dan Raden Pamekas.

Setelah Raden Patah meninggal, maka tahta kerajaan digantikan oleh anaknya yaitu Pangeran Sabrang Lor. Waktu Pangeran Sabrang Lor di belakang hari juga meninggal, yang menggantikannya Pangeran Trenggono. Menurut hukum yang sebenarnya yang berhak menggantikan Pangeran Sabrang Lor tidak lain adalah Pangeran Sido Lepen, adiknya yang paling tua. Akan tetapi oleh karena Pangeran Sedo Lepen telah meninggal, sebagai penggantinya ditunjuk Pangeran Trenggono2 dari Pangeran Trenggono ini sejarah asal-usul Ratu Kalinyamat diketahui.

Ratu Kalinyamat adalah Putri dari Sultan Trenggono (Raja Demak ketiga) sebagai cucu dari raja Demak I (Raden Patah) yang nama aslinya adalah Ratna Kencana dan menikah dengan Pangeran Hadirin. Sedang nama kalinyamat itu sebenarnya merupakan sebuah nama julukan pada suatu tempat, yaitu ibu kota Jepara pada waktu itu berada di daerah Kalinyamatan. Baik nama Kalinyamat maupun kedudukannya sebagai ibu kota kerajaan Jepara, tersebut dengan tegas dalam sumber sejarah Portugis dalam bukunya yang terkenal "De Asia" Penulis Portugis "Deige De Couto" telah menyebut kerajaan-kerajaan di pulau Jawa termasuk Jepara "Cujaidede Principal Se Chama Cerinhama" yang ibukotanya bernama Kalinyamat. Adapun mengenai kapan Ratu Kalinyamat lahir sampai sekarang belum dapat dipastikan oleh ahli sejarah. Namun di sini penulis akan mencoba mengira-ngira. Sebagaimana yang tertulis dalam buku Hari Jadi Jepara bahwa Sultan Trenggono lahir pada Tahun 1483 dan wafat pada Tahun 1546 dan dia naik tahta Tahun 1524.Dari Tahun ini dapat penulis ambil kesimpulan kira-kira kelahiran Ratu Kalinyamat Tahun 1508 karena Tahun 1550 dia sudah mengadakan pertempuran dengan Portugis ke Malaka. Kiranya kuranglah lengkap apabila sejarah Ratu Kalinyamat ini tidak disertakan pula asal-usul perkawinannya dengan Pangeran Hadirin. Siapakah sebenarnya Sultan Hadirin ini? Karena dari sini akan menelurkan legenda-legenda yang patut disimak oleh sejarah. Perihal ini ada beberapa versi: a. Menurut keterangan Prof. Veth, Pangeran Hadirin adalah putera Bupati Jepara.

Setelah sepeninggalan Sultan Trenggono dia diberi wilayah Pati, Juana, Jepara dan Rembang b. Menurut laporan komisi di Hindia Belanda untuk kepentingan kepurbakalaan di Jawa dan Madura Tahun $1910 \mathrm{~J}$. Knebel memberi keterangan bahwa Pangeran Hadirin adalah putera Cirebon, nama aslinya Raden Mu'min. dia berkelana dan tiba di Demak dan dia ingin mengabdi pada Raja Demak III (Trenggono). Permohonannya diterima dan akhirnya diterima sebagai menantu dan lama kelamaan diangkat menjadi Raja Kalinyamat.

Pemerintahan Ratu Kalinyamat adalah simbol kepahlawanan seorang putri sebagai tokoh wanita abad ke-16. DR HJ DE Graff sejarawan Belanda yang banyak menggeluti sejarah Jawa dalam bukunya awal kebangkitan Mataram menulis bahwa Ratu Kalinyamat telah dua kali menyerang Portugis dan Malaka yakni pada Tahun 1550 dan Tahun 1574. Namun mengalami kegagalan dan Ratu masih tetap berkuasa dan terus berusaha mengadakan serangan lagi. Serangan yang kedua itu berkekuatan 300 kapal layar yang 80 buah diantaranya berukuran besar masing-masing berbobot 400 ton, serta sekitar 15.000 prajurit pilihan yang dibekali meriam dan mesiu.

Sebagaimana pembahasan di bagian depan yaitu terjadinya perebutan tahta kerajaan Demak oleh Ario Penangsang dengan membunuh Sultan Prawata sebagai pewaris raja Demak III dengan motif menuntut balas kematian ayahnya yang mestinya lebih dahulu menjadi raja ketimbang Sultan Trenggono. Untuk mewujudkan cita-citanya menjadi raja Demak maka setelah Sunan Prawata meninggal, Sultan Hadirin juga menjadi penghalangnya, akhirnya Sultan Hadirin juga terkena pembunuhan tatkala pulang dari kasunanan kudus. Ratu kalinyamat merasa prihatin atas kematian saudaranya dan suaminya maka dia pergi bertapa untuk meminta 
pengadilan kepada yang kuasa.

Di dalam kedua sumber diatas disebutkan bahwa Ratu Kalinyamat bertapa dengan telanjang. Benarkah demikian? Di sini perlu penulis jelaskan bahwa para pujangga zaman dulu mempunyai kebiasaan tidak berbicara terus terang. Mereka sering menggunakan kiasan tersamar. Dalam bahasa Jawa wudo (telanjang) bisa berarti tidak mengenakan pakaian tapi juga bisa berarti tidak memakai barang-barang perhiasan dan pakaian yang bagus-bagus. Jika demikian maka "Wudo" artinya kiasan. Interpretasi ini sesuai dengan pendapat Drs. Uka Sasmita yang pernah mengemukakan pendapatnya bahwa untuk menebus jiwa suaminya yang dicintai itu ia (Ratu Kalinyamat) bertekat melakukan tapa dengan tidak menghiraukan pakaian dan makanan apapun. Dengan mengemukakan pendapat tadi maka tapa wuda Ratu kalinyamat harus diartikan secara kias bukan secara harfiyah.

Situs pertapaan Ratu Kalinyamat terdapat di tiga tempat. Yang pertama beliau bertapa tidak jauh dari pesanggrahannya, hanya beberapa meter kearah timur. Di situ ada tempat yang luas dengan pohon besar yang rimbun, apalagi letaknya ada di pinggir sungai. Maka tempat itu betul-betul cocok untuk bertirakat. Tempat itu kemudian hingga sekarang disebut dengan nama "gilang". Berasal dari kata gilang-gilang atau luas. Bahkan masih ditemukan di situ batu bekas alas sembahyang sang Ratu dan pancuran tempat berwudu. 23 Kabar pertapaan Ratu Kalinyamat sampai ke Pajang terdengar olah Hadiwijaya, setelah mendapatkan pengarahan dari Ki Panjawi, Hadiwijaya memutuskan untuk pergi menjenguk kakaknya kesana, ia membujuk kakak iparnya itu berkenan meninggalkan pertapaan dan kembali ke keratin. Tetapi sang ratu telah bertekat bulat. Bahkan akhirnya Ratu Kalinyamat memindah tempat pertapaannya ke Gunung Donoroso yang sekarang berada di Desa pengkol (Loji Gunung), karena di sini juga dikira sudah tidak memungkinkan lagi untuk menenagkan pikiran, maka Ratu Kalinyamat pindah lagi untuk mencari tempat yang tepat.

Maka sang ratu memutuskan untuk mencari tempat itu bersama beberapa dayangnya Selama dalam perjalanan setelah beberapa hari melakukan perjalanan, rombongan Ratu Kalinyamat bertemu dengan seorang yang bernama Ki Pejing, Ki Pejing menunjukkan tempat yang sangat bagus untuk bertapa, yaitu tempat di tepi sungai kecil yang airnya jernih dan selalu mengalir sepanjang Tahun, disamping itu tanah yang ditunjukkan tersebut berbau harum, karena baunya yang harum maka tempat yang akan dijadikan pertapaan Ratu Kalinyamat disebut sebagai sitiwangi ( siti = tanah wangi = harum, jadi tanah yang berbau harum). Setelah segalanya dipersiapkan Ratu Kalinyamat sebelum mulai bertapa terlebih dahulu mandi dan bersuci (wudlu) di sungai kecil yang berada di samping pertapaan tersebut. Namun Hadiwijaya tidak putus asa, ia tetap memutuskan untuk pergi menyusul kakaknya kesana.

Sultan lalu pergi ke lereng gunung Donorojo pada malam hari bersama Ki Pemanahan, Ki Panjawi, dan ketiga Raden Ngabehi loring Pasar (Danag Sutawijaya), setelah sampai di tempat pertapaan Ratu Kalinyamat berkata, "Adimas Prabu, apa maksud kedatanganmu kemari?" Sultan pajang menjawab, "Mbakyu meninggalkan negeri, bertapa di Gunung Donorojo serta tidak berkain, apakah yang menjadi kesusahan hati Mbakyu: Sultan Pajang berusaha menghibur, adapun kematian kakang sudah menjadi takdir Allah," Ratu Kalinyamat berkata, "aku sangat bahagia dengan kedatanganmu kemari akan tetapi aku sudah bertekat bahwa sebelum mendapatkan keadilan dari Gusti Allah, saya tidak akan memakai kain sebelum Arya Penangsang yang menimbulkan keonaran, dan pembunuhan dapat dihukum sesuai dengan angkara yang diperbuat," Ratu Kalinyamat meneruskan perkataannya, "dan barang siapa yang mampu mengembalikan keadaan dengan meringkus orangorang yang telah berbuat $d z$ olim maka kekayaan dan kerajaan yang saya miliki akan saya berikan kepada orang tersebut". Sultan Pajang tertegun mendengar perkataan sang ratu, Sultan Pajang sebetulnya bermaksud menolong Ratu Kalinyamat untuk meringkus Arya Penangsang, akan tetapi tidak berani karena Arya penangsang adalah jagoan pilih tanding pada waktu itu. Atas dorongan dari Ki Panjawi Sultan Pajang berani memutuskan untuk meringkus Arya Penangsang, setelah terjadi musyawarah panjang antara Ki Panjawi, Ki Pemanahan, dan Ki MenTahun. Akhirnya Arya Penangsang (Adipati Jipang) bisa diringkus di tangan Raden Ngabehi Loring Pasar.

\subsection{Petilasan Pertapaan Ratu Kalinyamat}

Selendang dan bekas pertapaan Ratu Kalinyamat masih berada di dalam pendopo yang memiliki ukuran sekitar $10 \times 8 \mathrm{~m}$ tersebut. Dilihat dari segi bangunan pendopo tersebut masih terlihat kokoh dan terawat. 


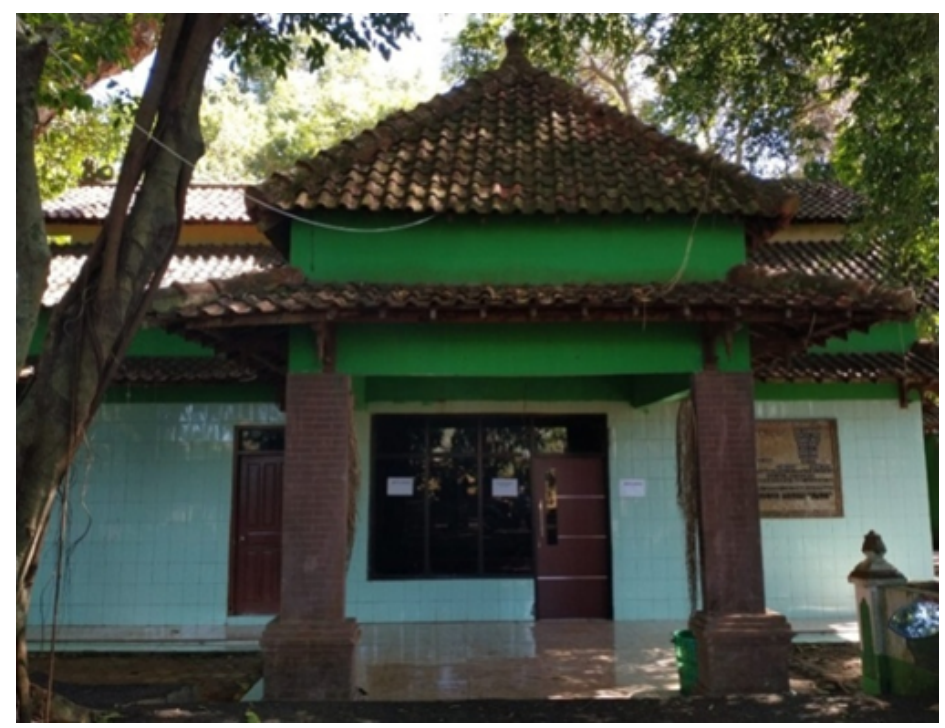

Gambar 1. Pendopo Pertapaan Ratu Kalinyamat

Lingkungan petilasan ratu kalinyamat dibagi menjadi beberapa bagian diantaranya, gerbang pintu masuk yang memiliki estetika bangunan kuno yang menggambarkan kekokohan bangunan, setelah peneliti masuk kedalam disebelah utara terdapat pepohonan yang rimbun, mulai dari pohon beringin, rumput- rumput liar, serta ada sebuah sumur. Berjalan kearah selatan terdapat sebuah bangunan yang sering penduduk sebut sebagai pendopo pertapaan ratu kalinyamat yang menghadap kearah timur, yang didalamnya terdapat sebuah petilasan pertapaan yang digunakan oleh ratu kalinyamat. Peneliti berjalan ke arah sungai yang mengalir dari barat ke timur dan terdapat sebuah aliran sungai yang digunakan untuk berwudhu, menurut keterangan penjaga atau juru kunci tempat tersebut adalah sebuah peninggalan dari dahulu kala. Dan di depan pendopo terdapat dua pohon beringin besar.

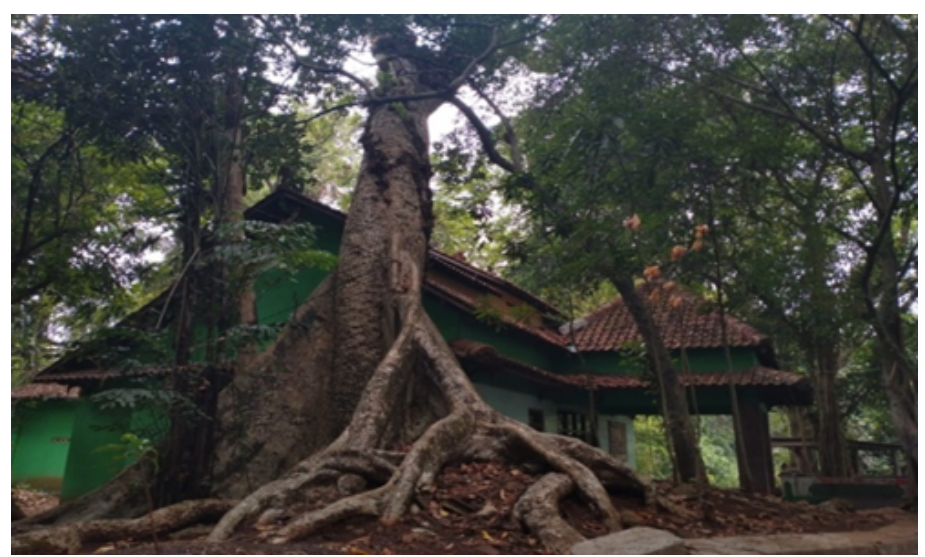

Gambar 2. Pohon Beringin di Area Pendopo Pertapaan Ratu Kalinyamat

Petilasan pertapaan Ratu Kalinyamat ini sering melaksanakan Tradisi Melekan pada malam Jumat Wage. Tradisi ini dilakukan semalam suntuk tidak diperbolehkan tidur, hanya boleh berdzikir serta berdoa kepada sang maha kuasa. Hasil wawancara dengan salah satu tokoh masyarkat di desa tulakan yakni Bapak Budi Sutrisno, S.Pd menghasilkan cerita rakyat yang memiliki sangkut paunya dengan sebuah tradisi yakni Tradisi Melekan setiap Jumat Wage.

Adanya keterlibatan masyarakat dalam kegiatan di petilasan pertapaan Ratu Kalinyamat membuktikan bahwa terdapat apresisi yang bagi dari masyarakat, terutama maksyarakat Desa Tulakan dalam melestarikan petilasan tersebut sebagai warisan budaya. Sebagaimana yang dikemukakan oleh Candra (2020) yang meny- 
atakan bahwa sikap sosial yang baik dari masyarakat terhadap suatu budaya, mencerminkan toleransi dan menjadi hasil dari sebuah apresiasi.

Dari hal-hal tersebut dapat diketahui bahwa nilai-nilai religius cerita rakyat pertapan Ratu Kalinyamat sangat kental dilingungan masyarakat Desa Tulakan dan sekitarnya, sesuai dengan hasil wawancara peneliti dengan juru kunci, peziarah, kepala desa dan masyarakat sekitar yang memahami cerita rakyat pertapaan Ratu Kalinyamat serta melaksanakan kegiatan yang dilaksanakan di petilasan pertapaan Ratu Kalinyamat.

\subsection{Nilai Karakter Religius Cerita Rakyat Pertapaan Ratu Kalinyamat untuk Siswa Sekolah Dasar}

Cerita Rakyat Pertapaan Ratu Kalinyamat ini memiliki nilai karakter Religius yang sangat dominan. Berdasarkan teori yang dikemukakan oleh Glok dan Strack dalam Subandi (2013), aspek atau dimensi religius diantaranya adalah:

a Religious Belief (Dimensi Keyakinan). Dimensi keyakinan yaitu tingkatan sejauh mana seseorang menerima hal-hal yang dogmatik dalam agamanya. Ratu kalinyamat merupakan istri dari seorang sultan hadirin yang merupakan salah satu wali yang menyebarkan agama islam di daerah Jepara secara khususnya. Dikisahkan beliau adalah seseorang yang taat beragama, mempercayai adanya tuhan, malaikat, kitab, rosul, hari kiamat dan takdir baik buruk dari Allah.

b Religious Practice (Dimensi Menjalankan Kewajiban). Dimensi ini adalah dimana peserta didik memiliki tingkatan sejauhmana seseorang mengerjakan kewajiban-kewajiban ritual agamanya seperti melaksanakan ibadah shalat wajib dan sunah, berpuasa wajib dan sunah, berdoa sebelum dan sesudah melakukan sesuatu, berinfak, shodakoh dan lain sebagainya.

c Religious Feeling (Dimensi Penghayatan). Dimensi pengalaman dan penghayatan beragama yaitu perasaan-perasaan atau pengalaman-pengalaman keagamaan yang pernah dialami dan dirasakan. Misalnya merasa dekat dengan Tuhan, merasa takut ketika peserta didik melakukan sebuah dosa atau kesalahan, merasa diselamatkan oleh Tuhan dan lain sebagainya.

d Religious Knowledge (Dimensi Pengetahuan). Dimensi pengetahuan yaitu seberapa jauh seseorang mengetahui tentang ajaran-ajaran agamanya, terutama yang ada dalam kitab suci maupun yang lainnya. Dimensi ini juga disebut dimensi ilmu yang dalam Islam termasuk pengetahuan ilmu fiqih.

e Religious Effect (Dimensi Perilaku). Dimensi ini merupakan dimensi yang mengukur sejauh mana perilaku seseorang yang dimotivasi oleh ajaran agamanya dalam kehidupan sosial. Misalnya peserta didik mengunjungi tetangganya yang sakit, menolong orang lain yang kesulitan, mendermakan harta dan sebagainya.

Berdasarkan hasil observasi, wawancara dan dokumentasi oleh peneliti terhadap informan penelitian seperti juru kunci petilasan, Kepala Desa Tulakan, peziarah, masyarakat Desa Tulakan, guru sekolah dasar selaku praktisi pendidikan dan siswa sekolah dasar, cerita rakyat pertapaan Ratu Kalinyamat memenuhi ke-5 dimensi tersebut. Peneliti berpendapat dalam cerita rakyat pertapaan Ratu Kalinyamat ini dikontuksikan mengandung nilai karakter religius yang dapat tercermin dalam sikap dan tindakan manusia. Sikap perilaku yang patuh terhadap ajaran agama yang dianut serta menjauhi larangan-Nya, dapat ditanamkan dalam pendidikan anak sekolah dasar melalui berbagai kegiatan pembelajaran.

\section{SIMPULAN}

Nilai karakter yang terkandung dalam cerita rakyat pertapaan Ratu Kalinyamat adalah karakter religius dengan lima aspek dimensi yaitu Religious Belief (Dimensi Keyakinan), Religious Practice (Dimensi Menjalankan Kewajiban), Religious Feeling (Dimensi Penghayatan), Religious Knowledge (Dimensi Pengetahuan),serta Religious Effect (Dimensi Perilaku).

\section{DAFTAR PUSTAKA}

Agung, L. (2018). Character Education Integration In Social Studies Learning. Historia: Jurnal Pendidik dan Peneliti Sejarah, 12(2), 392. doi:10.17509/historia.v12i2.12111 
Candra, W. (2020). Perkembangan Sikap Sosial Anak melalui Proses Apresiasi terhadap Tradisi Sambatan di Desa Dermolo, Jepara. DIDAKTIKA: Jurnal Pendidikan Sekolah Dasar, 3(1), 57-64. doi:10.21831/ didaktika.v3i1.30932

Faishol, A., \& Bakri, S. (2014). Islam dan Budaya Jawa. Surakarta: Pusat Pengembangan Bahasa IAIN Surakarta.

Kanzunnudin, M. (2015). Cerita Rakyat sebagai Sumber Kearifan Lokal. In Makalah disajikan dalam seminar kebudayaan pusat studi kebudayaan universitas muria kudus, di kudus.

Lozar, C., \& Rapoport, A. (1970). House Form and Culture. Journal of Aesthetic Education. doi:10.2307/ 3331293

Miles, M. B., \& Huberman, M. A. (2012). Analisis Data Kualitatif: Buku Sumber Tentang Metode-Metode Baru.

Moleong, L. J. (2017). Metodologi Penelitian Kualitatif (Edisi Revisi). Jakarta: PT Remaja Rosdakarya.

Nurgiyantoro, B. (2015). Teori pengkajian fiksi. In Teori pengkajian fiksi. Yogyakarta: Gadjah Mada University Press.

Subandi, M. (2013). Psikologi agama dan kesehatan mental. Yogyakarta: Pustaka Pelajar.

Sugirin, S. (2018). Role models in language acquisition and character education. In Character education for 21 st century global citizens (pp. 451-457). doi:10.1201/9781315104188-58

Sugiyono. (2016). Metode Penelitian dan Pengembangan (Research and Development/R\&D). Bandung: Alfa Beta. 